\title{
A Case for the History of Ideas
}

\section{Brett Bowden 1}

School of Humanities \& Communication Arts, Western Sydney University, Penrith 2751, Australia; b.bowden@westernsydney.edu.au

Received: 13 October 2020; Accepted: 14 October 2020; Published: 28 October 2020

As a graduate student, I undertook my doctoral training in a Political Science Program. I have never considered myself a political scientist, however. Rather, I have always been more interested in the ideas and concepts that shape politics and society. The ideas and concepts that make and shape history. There are many ways of "doing history" - telling stories about the key people, places, events and times, or telling stories of the "everyday" or "common" people-but for my mind, it is ideas that matter. The words of a number of prominent thinkers point to why this is so. Ever since I first read it, I have been struck by John Maynard Keynes's suggestion that "the ideas of economists and political philosophers, both when they are right and when they are wrong, are more powerful than is commonly understood. Indeed the world is ruled by little else ... soon or late, it is ideas, not vested interests, which are dangerous for good or evil". The gravity of this suggestion is emphasised by Terry Eagleton's observation that "ideas are what men and women live by, and will occasionally die for". Finally, H. G. Wells captures the breadth and depth with his insistence that "all human history is fundamentally a history of ideas" ${ }^{\prime 1}$. My own interests in this realm have involved exploring the idea of civilization, both its descriptive and normative elements, including the many unsavoury things done in the name of civilization. Closely related to this is work I have undertaken on the idea of progress and its relationship to universal history. More recently, I have done some digging on the origins and varied meanings of the term frontier. The first known recorded use was in Spanish-frontera-in the twelfth century, and it remains just as relevant today as it was more than eight hundred years ago ${ }^{2}$.

There is more to the history of ideas and conceptual history than simply tracing the genealogy of key or contested concepts. So too, historians of ideas are more than archaeologists picking over the bones of ancient manuscripts. As an intellectual exercise, it is a long way from a "purely academic or antiquarian" practice; rather, it is about tracing the "thread of life and language" that connects the present with the past and, no less importantly, the future. Such histories can bring with them an "emancipatory effect" of opening up the terms of discourse and debate, which allows "us to escape the politically stultifying confines of a parochial and increasingly dangerous present" ${ }^{\prime 3}$. As Joseph Mazzeo has put it, at its best, the history of ideas is in fact "the study of the life of ideas". When done well, it serves "to correct the simplistic but widespread notion that philosophers and scientists do all the thinking while poets and artists simply feel or perceive" ${ }^{\prime 4}$. A noble and worthwhile enterprise indeed.

Just as there are manifold methods of doing history, there are also many ways to explore the history of ideas; one approach that I have found helpful in my own work is conceptual history. As Kai Vogelsang, a German with an interest in Sinology, notes, in order to have an accurate "description of past ages, it is imperative 'that the terminology it uses is derived, as far as possible, from the sources themselves, so that the meaning of these sources may be correctly interpreted with the help of

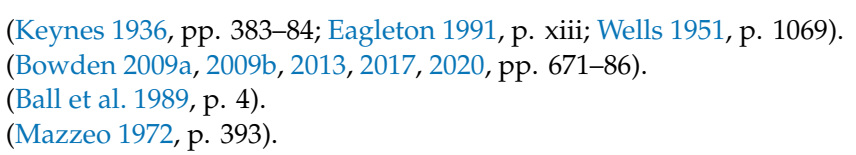


these concepts". As he adds, "Conceptual history, then, was conceived as an ancillary discipline of history" $^{\prime \prime}$. This description fits well with the prominent Cambridge School approach to the history of ideas and political thought ${ }^{6}$. The Cambridge School style approach to textual research and analysis is well known for the emphasis and significance it places on the language of political thought and the relationship between thought and action. It is also noted for the significant consideration it gives to both biography or experience, and contextualism, or the study of texts in context. The approach recognizes that texts and experiences or actions are best understood in context and through having a broader understanding of that context. More generally, the Cambridge School "method should be seen as essentially archaeological, concerned as it is with elucidating the concepts through which human collectivities organize and constitute themselves and the meaningful shift(s) in such understandings" ${ }^{\prime 7}$.

The link between language and action, or political thought and political practise and outcomes is captured in Quentin Skinner's assertion of the "fact that to make a statement is to perform an action". He goes on to explain, the "fact that a knowledge of the context of any given text does help in understanding it reflects the fact, surely undeniable, that for the performance of any action-and the making of statements is surely to be appraised as a performance-it will always be possible at least in principle to discover a set of conditions either such that the action (the statement made) might have been different or might not have occurred in their absence, or even such that the occurrence of the action might have been predicted from their presence". Skinner concludes that there "seems no question that for every statement there must be some explanatory context, for every action some set of antecedent causal conditions" ${ }^{\prime 8}$.

J.G.A. Pocock, another founding father of the Cambridge School, is instructive for the historian of ideas when he highlights that the "practical and the theoretical are not separable" and writes of "the functions within a political society of what may be called its language (or languages) of politics". He recognizes that a "stable and articulate society possesses concepts with which to discuss its political affairs". Moreover, according to Pocock, the "business of the historian of thought is to study the emergence and roles of the organizing concepts" that are employed in a given society. He acknowledges that this is no straightforward task, for there "is a gap between thinking and experience; but it is the business of the historian of political ideas to inhabit that gap and try to understand its significance". Pocock reminds us that "the knowledge that this role has necessary limitations need not deter" one from undertaking such challenging yet critical exercises. The connections between ideas and outcomes will not always be straightforward or obvious, but to "deny that concepts may be isolated and shown to play a determining role in politics is not to deny that they play any role whatever". At times there might only be circumstantial evidence of causal links between thought and action, but that does not mean that ideas have not been influential in making policy and pursuing outcomes. As noted, an appreciation of ideas in context is an important consideration in the methodology of the Cambridge School. In this regard, similar to Skinner, Pocock notes that "much (though not all) political thinking does take shape in an immediate practical context". He goes on to stress that it "is of some importance to be able to interpret thought by placing it in the tradition of discourse to which it rightfully belongs; and this is for two reasons". First, "it enables us to interpret thought as social behaviour, to observe the mind acting with relation to its society, that society's traditions and its fellow-inhabitants of that society" and second, "it is of assistance in rendering thought intelligible to be able to identify the concepts which the thinker was handling and the language in which he was communicating with his fellow-men; what he was talking about and what he was taken to mean" ${ }^{\prime 9}$.

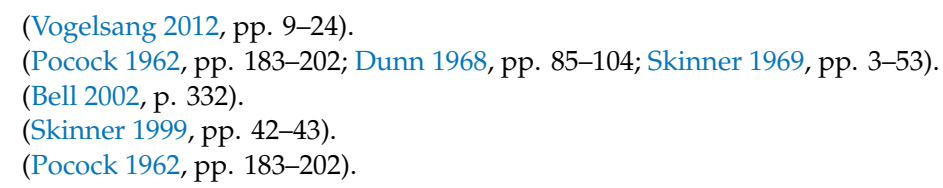


In a similar vein of thought, John Dunn, the third significant figure identified with the emergence of the Cambridge School, asserts that "the connection between an adequate philosophical account of the notions held by an individual in the past and an accurate historical account of these notions is an intimate one; that both historical specificity and philosophical delicacy are more likely to be attained if they are pursued together, than if one is deserted for the other at an early stage of the investigation". Similar to Skinner, Dunn makes the point that "few branches of the history of ideas have been written as the history of an activity". In doing so, he is emphasizing that there is an inherently strong connection between ideas and actions. He goes on to note that "language is not ... a repository of formal truths donated by God to Adam but simply the tool which human beings use in their struggle to make sense of their experiences", adding that "talking and thinking" should be "considered seriously as social activities". Further, in relation to the importance of context, Dunn argues that if "we are to understand the criteria of truth or falsehood implicit in a complex intellectual architectonic, we have to understand the structures of biographical or social experience which made these criteria seem self-evident. To abstract an argument from the context of truth-criteria which it was devised to meet is to convert it into a different argument". In essence, Dunn contends that the history of ideas is concerned with at least two things: "the set of argued propositions in the past which discuss how the political world is and ought to be and what should constitute the criteria for proper action within it; the set of activities in which men were engaged in when they enunciated these propositions" ${ }^{\prime 10}$.

The Cambridge School approach to the history of ideas can be summarized as "rooted in the role of language in the establishment, communication, and reproduction of political legitimacy. In particular, it concentrates on the role of politico-moral concepts through which we order social and political life and by which we are in turn ordered, and the manner in which such concepts are manipulated and embedded in the discursive construction" of politics, economy, society and more. Duncan Bell makes the important that no one approach is likely to be sufficient "to answer the inevitable, timeless problems of interpretation ... and the intellectual historian should always remain open to divergent methodological perspectives, to the plurality of reading strategies"11. Another approach to the history of ideas that I have found useful is the German mode of inquiry, known as Begriffsgeschichte, the history of concepts or conceptual history, which is perhaps best considered as "more a procedure than a definite method"12. As noted, there is more to this form of history than etymological explorations or noting the changes over time in the meaning of a concept. Many historians go along with Johann Gottfried Herder's suggestion that the "present [is] pregnant with the past", which is to say, "the present owes its existence to the past, as the future will be beholden to the present". A geologist who subscribes to uniformitarianism, on the other hand, would invert that idea to assert that the present is the key to the past ${ }^{13}$. Either way, the point of conceptual history and the history of ideas more generally "is not to restore the past but to remember it and to retrace the path to present"14. For as Skinner poignantly notes, history and the understanding of history are important not so much "because crude 'lessons' can be picked out of them, but because the history itself provides a lesson in self-knowledge"15.

As is the case with many different methods or approaches to the study of history, Begriffsgeschichte and the Cambridge School need not be thought of as incompatible or in competition. Melvin Richter points out that the German procedure and the work of Pocock and Skinner in particular share "a common concern with political language treated historically, and the insistence on both sides that political thought and behaviour, now and in the past, cannot be understood without reference to the distinctive vocabularies used by agents in given contexts"16. Skinner has acknowledged the

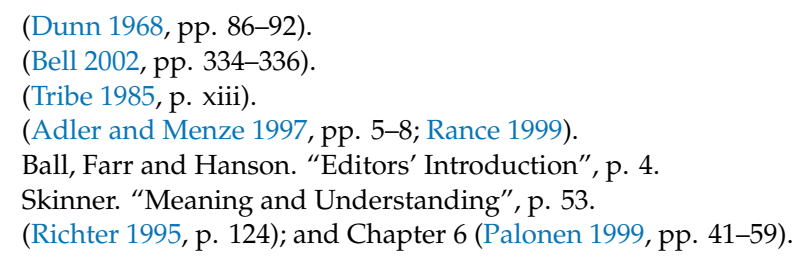


complementary attributes of the two approaches and praised the work of Reinhart Koselleck, a leading architect and practitioner of Begriffsgeschichte. Skinner writes that he has "not only been innocent of any desire to question Koselleck's methodological assumptions, but that [he has] ... even attempted to write some conceptual histories." Moreover, he recognizes "that if we are interested in mapping the rise and fall of particular normative vocabularies, we shall have to devote ourselves to examining the longue durée". Skinner goes on to note that his "own research-programme might even be regarded as an aspect of the vastly more ambitious one pursued by Koselleck". He adds, "Koselleck is interested in nothing less than the entire process of conceptual change;" whereas he is "chiefly interested in one of the means by which it takes place". Skinner concludes that the "two programmes do not strike... [him] as necessarily incompatible"17.

The history of ideas well equipped to help us better understand the past so that we may better understand the present, and in doing so hopefully avoid replicating the mistakes or indiscretions of the past. As Ball, Farr and Hanson write in respect to ideas and actions, "remembering [and acknowledging] our past enables us to have a clearer-and perchance a more critical-perspective on our present". The history of ideas, then, is not about drawing parallels between past and present, and it is not about drawing the unsustainable conclusion that the exploitation of certain ideas or language have led to certain outcomes in the past; therefore, the same outcomes will inevitably be replicated if similar ideas and language are adopted in the present or the future. One advantage of demonstrating the power of ideas and offering examples of past relationships between thought and action is to warn of possible outcomes or consequences associated with certain conceptual and language choices.

As an approach to the study of history, the history of ideas offers a wider and deeper self-knowledge and understanding that can help circumvent what Ball, Farr and Hanson describe as the "little wonder" that there are concerted and ongoing "attempts to control the past [and through it the present] by rewriting history or, failing that, by obliterating memory altogether." As they further warn, people "adrift in the present and cut off" from the past and the understanding that might be gleaned from it, become more manipulable and pliable subjects". In a particularly troubled time, such as we find ourselves in 2020, a period over which hangs the shadows of climate change and a global pandemic, both exacerbated by political populism, the risks of remaining lost or blinded, are too great to contemplate. In an age when people speak of "alternative facts" and "fake news", while at the same time undermining the rigours of the scientific method, we are obliged to reflect and "retrace our steps" 18 . The history of ideas can serve as an invaluable tool in helping us to remove a blindfold or shine a light into dark and forgotten corners as we rediscover the past so that we may understand the present.

Funding: This research received no external funding.

Conflicts of Interest: The author declare no conflict of interest.

\section{References}

Adler, Hans, and Ernest A. Menze. 1997. Introduction: On the Way to World History: Johann Gottfried Herder. In Johann Gottfried Herder, On World History: An Anthology. Edited by Hans Adler and Ernest A. Menze. Translated by Ernest A. Menze, and Michael Palma. Armonk and London: M.E. Sharpe, pp. 3-19.

Ball, Terence, James Farr, and Russell L. Hanson, eds. 1989. Editors' Introduction. In Political Innovation and Conceptual Change. Cambridge: Cambridge University Press, pp. 1-5.

Bell, Duncan S. A. 2002. Language, legitimacy, and the project of critique. Alternatives: Global, Local, Political 27: 327-50. [CrossRef]

Bowden, Brett, ed. 2009a. Civilization: Critical Concepts in Political Science. 4 vols. London and New York: Routledge.

17 (Skinner 1999, pp. 62-72; Koselleck 1985).

18 Ball, Farr, and Hanson. "Editors' Introduction", pp. 4-5. 
Bowden, Brett. 2009b. The Empire of Civilization: The Evolution of an Imperial Idea. Chicago and London: University of Chicago Press.

Bowden, Brett. 2013. Civilization and War. Cheltenham: Edward Elgar.

Bowden, Brett. 2017. The Strange Persistence of Universal History in Political Thought. New York: Palgrave Macmillan. Bowden, Brett. 2020. Frontiers-Old, New and Final. European Legacy: Toward New Paradigms 25: 671-86. [CrossRef] Dunn, John. 1968. The Identity of the History of Ideas. Philosophy 43: 85-104. [CrossRef]

Eagleton, Terry. 1991. Ideology: An Introduction. London and New York: Verso.

Keynes, John Maynard. 1936. The General Theory of Employment, Interest and Money. London: MacMillan \& Co.

Koselleck, Reinhart. 1985. Futures Past: On the Semantics of Historical Time. Translated by Keith Tribe. Cambridge: MIT Press.

Mazzeo, Joseph Anthony. 1972. Some Interpretations of the History of Ideas. Journal of the History of Ideas 33: 393. [CrossRef]

Palonen, Kari. 1999. Rhetorical and Temporal Perspectives on Conceptual Change. Finnish Yearbook of Political Thought 3: 41-59. [CrossRef]

Pocock, John G. A. 1962. The History of Political Thought: A Methodological Enquiry. In Philosophy, Politics, and Society. Second Series. Edited by Peter Laslett and W. C. Runicman. Oxford: Blackwell, pp. 183-202.

Rance, Hugh. 1999. Historical Geology: "The Present is the Key to the Past": A Study of the Prehistory of the Earth and Life. New York: QCC Press.

Richter, Melvin. 1995. The History of Political and Social Concepts: A Critical Introduction. Cambridge: Cambridge University Press.

Skinner, Quentin. 1969. Meaning and Understanding in the History of Ideas. History and Theory 8: 3-53. [CrossRef] Skinner, Quentin. 1999. Rhetoric and Conceptual Change. Finnish Yearbook of Political Thought 3: 60-72. [CrossRef] Tribe, Keith. 1985. Translator's Introduction. In Reinhart Koselleck, Futures Past: On the Semantics of Historical Time. Translated by Keith Tribe. Cambridge: MIT Press, pp. vii-xvii.

Vogelsang, Kai. 2012. Conceptual History: A Short Introduction. Oriens Extremus 51: 9-24.

Wells, H. G. 1951. The Outline of History: Being a Plain History of Life and Mankind, rev. ed. London: Cassell \& Co.

Publisher's Note: MDPI stays neutral with regard to jurisdictional claims in published maps and institutional affiliations.

(C) 2020 by the author. Licensee MDPI, Basel, Switzerland. This article is an open access article distributed under the terms and conditions of the Creative Commons Attribution (CC BY) license (http://creativecommons.org/licenses/by/4.0/). 